\title{
Luomutuottajien kokemuksia luomu-kevätrypsin viljelystä
}

\author{
Kaija Hakala
}

MTT (Maa- ja elintarviketuotannon tutkimuskeskus), Kasvintuotannon tutkimus, 31600 Jokioinen, kaija.hakala@mtt.fi

\section{Tiivistelmä}

MTT haastatteli yhteistyössä Proagrian luomuneuvojien kanssa 56 luomu-kevätrypsin viljelijää. Kysyimme, miten he ovat viljelleet kevätrypsiä (maan muokkaus, kylvöaika, kylvöpäivä, viljelykierto, rikkakasvien, tautien ja tuholaisten torjunta, lannoitus), minkälaisia tuloksia he ovat saaneet, mitkä asiat he kokevat ongelmallisiksi luomukevätrypsin tuotannossa ja miten rypsin markkinat ja hinta ovat toimineet.

Haastateltujen tuottajien kokonaisviljelyalat olivat usein yli 100 ha suuruisia. Rypsin viljelyalat olivat yleensä 5-15 ha ja rypsiä viljeltiin monenlaisilla lohkoilla. Monet olivat omien peltojensa lisäksi vuokranneet luomutuotantoon uutta peltoa, jolloin peltojen kasvukunto ja ravinnepitoisuus saattoivat vaihdella huomattavasti. Erityisenä tiedustelun kohteena oli vuoden 2010 sato, mikä oli melkein kaikilla ollut kuivuuden takia huono. Jotkut viljelijät olivat kuitenkin tuonakin vuonna onnistuneet erinomaisesti joillakin lohkoilla.

Luomuviljelijät kertoivat tuottavansa kevätrypsiä monista syistä, joista tärkeimmät liittyivät rypsin myöhäiseen kylvöön, yhteistyöhön naapurien kotieläintilojen kanssa, tukimahdollisuuksiin ja toimiviin markkinoihin. Rypsin myöhäinen kylvö mahdollistaa sadontuoton esim. lohkolla, jolla talvehtiva vilja tai nurmi ei ole onnistunut ja päätös kylvöksen rikkomisesta viipyy myöhään kevääseen. Myöhäinen kylvö mahdollistaa myös rikkakasvien hallinnan kevätkultivoinnein, mikä on tärkeää rikkapitoisten lohkojen kunnostuksessa ja uuden luomupellon käyttöönotossa. Rypsiä käytetään myös usein suojakasvina nurmelle, koska siitä saatava tuki on ollut hyvä. Monella viljelijällä on taustalla luomurinki tai joukko samanhenkisiä viljelijöitä, mikä mahdollistaa sujuvan markkinoinnin ja muuta yhteistyötä. Hyvin sujuvaa yhteistyö on etenkin kotieläintuotannon toimijoiden ja rypsin viljelijöiden kesken. Pahimpia viljelijöiden mainitsemia ongelmia ovat alkukasvukauden kuivuus ja sään ääri-ilmiöt, tuholaiset ja rikkakasvit sekä rypsin vaihteleva sato. Luomu-kevätrypsin hinta ja markkinat ovat kaikilla viljelijöillä toimineet hyvin.

Esityksessäni listaan tavallisimpia luomurypsin viljelykäytäntöjä ja tuotannon tuloksia. Esitän myös haastatteluissa esiin tulleita ongelmia ja niiden ratkaisuyrityksiä luomu-kevätrypsin viljelyssä sekä luomukevätrypsin tuotannon ja yleensäkin luomutuotannon hyviä ja huonoja puolia.

Tutkimus on osa OMAVARA (Kotimaisen valkuaisomavaraisuuden parantaminen globaalimuutosten paineessa) -projektia.

Asiasanat: luomutuotanto, kevätrypsi, haastattelu 


\section{Johdanto}

Palkokasvit (herne, härkäpapu, apila, virnat, ym.) ovat luonnollinen osa luomuviljelyn viljelykiertoa. $\mathrm{Ne}$ tuottavat systeemiin typpeä muun luonnonmukaisen lannoituksen lisänä. Lisäksi palkokasvit ovat avainasemassa kotieläintuotannon valkuaislähteenä. Lehmien ruokinnassa käytetään valkuaislisänä usein rypsiä, joka lisää maidontuotantoa jopa paremmin kuin tuontisoija (Rinne ym. 2006). Luomutuotannossa rypsi saattaa kuitenkin olla haastava viljeltävä monesta syystä. Se on altis tuholaisille, joiden torjuminen rypsikasvustosta on luomuviljelyssä kallista ja työlästä eikä tuloskaan ole aina varma. Lisäksi rypsi ei tuo maahan ravinteita, vaan päinvastoin tarvitsee paljon ravinteita hyvään sadon tuottoon (http://www.agronet.fi/rypsi2000/). Luomuviljelijän on harkittava, kannattaako maidontuotannon lisäys rypsirehulla, jos rypsin hehtaarisato jää pieneksi. Rypsiä kuitenkin viljellään melko paljon luomutuotannossa. Haastattelimme luomu-kevätrypsin viljelijöitä saadaksemme selville, miten, miksi ja millä menestyksellä he ovat luomu-kevätrypsiä viljelleet. Tutkimus on osa projektia Kotimaisen valkuaisomavaraisuuden parantaminen globaalimuutosten paineessa (OMAVARA).

\section{Aineisto ja menetelmät}

Tutkimukseen valittiin neljä ELY-keskus-aluetta, joiden luomu-kevätrypsin yhteispinta-alat olivat suurimmat sellaisilla tiloilla, joilta oli saatu suostumus yhteydenottoihin tutkimuksen tekoa varten. Yhteensä luomu-kevätrypsiä viljeltiin Suomessa tällaisilla tiloilla 2741 hehtaarilla vuonna 2010. Valituilla neljällä alueella, Pirkanmaa (511 ha), Varsinais-Suomi (407 ha), Kaakkois-Suomi (321 ha) ja Uusimaa (308 ha) viljeltiin luomu-kevätrypsiä yhteensä 1547 hehtaarilla. Jokaiselta alueelta valittiin ensin 15 tilaa siten, että mukaan tulivat 15 suurinta rypsin viljelijää vuonna 2010 (yhteensä 60 tilaa). Näiden tilojen haltijoihin otettiin yhteyttä kirjeitse ja sen jälkeen sähköpostitse ja lopulta puhelimitse, jollei sähköpostitse oltu saatu kyselyyn vastausta. Yhteensä vastaukset saatiin syksyyn 2011 mennessä 56 viljelijältä. Varsinais-Suomen alueelta vastasi 15, Pirkanmaalta 16, Uudeltamaalta 12 ja Kaakkois-Suomesta 13 viljelijää kyselyyn. Kysely jatkuu loppusyksystä 2011-keväällä 2012 vielä vuoden 2011 satotietojen tiedustelujen ja täydennysten merkeissä. Lisäksi toiveena on saada haastateltua lisää viljelijöitä Uudeltamaalta ja Kaakkois-Suomesta siten, että haastatteluun tulisi vähintään 60 täydellistä vastausta.

\section{Tulokset ja tulosten tarkastelu}

\section{Luomuun sürryttiin EU:n myötä, tilat ovat suuria ja rypsipellot pieniä}

Haastatteluun osallistuneet tilat ovat siirtyneet luomuun useimmiten Suomen EU:hun liittymisen jälkeen vuonna 1996. Luomurypsiä on viljelty 1-16 vuotta (jotkut koko luomu-ajan, Kuva 1). Tilat ovat keskimäärin suuria, usein yli 100 ha suuruisia (Kuva 2). Luomu-kevätrypsin viljelyalat sen sijaan ovat melko pieniä, yleensä noin 5-15 ha. Joskus rypsiä saattoi olla viljelyssä jopa 40 ha, jos tila oli oikein suuri (Kuva 3).

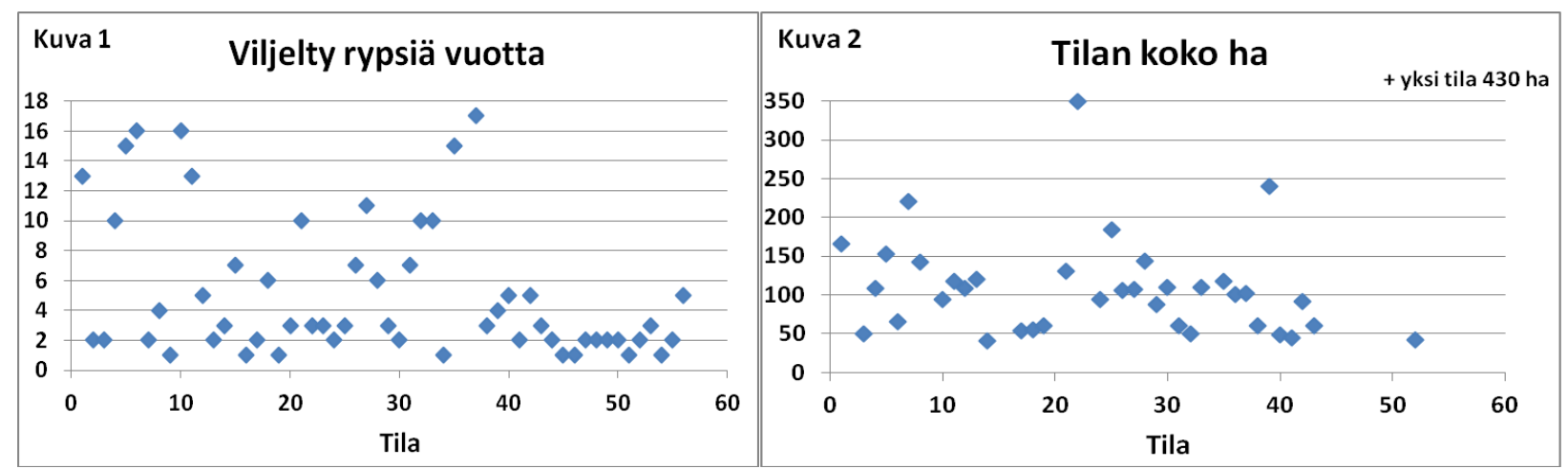

Kuva1. Rypsin viljelyhistoria (v). Tiedot 56 tilalta, joista tilat 1-12 ovat Uudenmaan-, 13-27 Varsinais-Suomen-, 2843 Pirkanmaan- ja 44-56 Kaakkois-Suomen ELY-keskus-alueelta.

Kuva 2. Tilat ovat suuria. Kaakkois-Suomen tieto puuttuu muilta paitsi yhdeltä tilalta. 
Viljelijät noudattavat tarkkaan ja jopa vähimmäisohjetta huolellisemmin rypsille asetettuja viljelykiertovaatimuksia (http://www.agronet.fi/rypsi2000/): rypsiä viljellään yleensä 4-5 vuoden välein (Kuva 4). Viljelykierron takia rypsiä viljellään monenlaisilla lohkoilla eikä vain sellaisilla, joille rypsi soveltuisi kaikkein parhaiten. Monet ovat omien peltojensa lisäksi vuokranneet luomutuotantoon uutta peltoa, joten peltolohkojen kasvukunto ja ravinnepitoisuus saattavat vaihdella huomattavasti. $\mathrm{pH}$ oli kuitenkin haastatelluilla tiloilla yleensä melko hyvä, keskimäärin 6. Myös ravinnetila oli yleensä tyydyttävä, joskin fosforista ja hivenaineista saattoi joskus olla puutetta.

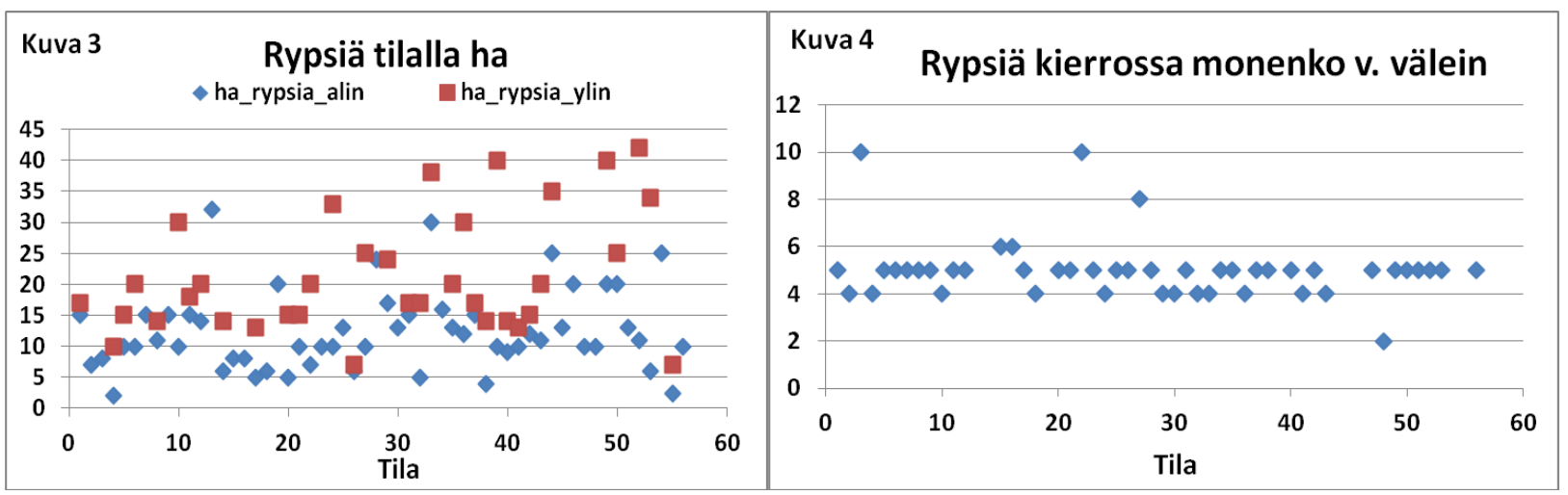

Kuva 3. Rypsin viljelyalat ovat yleensä melko pieniä.

Kuva 4. Rypsiä on kierrossa korkeintaan joka 4. vuosi. Tilojen sijainnit ELY-keskusalueittain, kts. Kuvan 1 teksti.

\section{Ei tauteja, vähän tuholaisia ja aina rikkoja: konstit ovat joko monet tai vähissä}

Tautiongelmaa on luomu-kevätrypsin viljelyssä harvoin, sillä rypsiä viljellään samalla pellolla yleensä korkeintaan joka neljäs vuosi (Kuva 4). Vain neljä viljelijää 56:sta oli havainnut luomu-rypsipellolla mitään tautiin viittaavaa. Sen sijaan etenkin huonoina vuosina riesana saattavat olla tuholaiset, jotka saattavat tuhota lyhyessä ajassa joko koko sadon tai esim. ojien reunat usean metrin leveydeltä (Kuva 5). Melkein aina ongelmana ovat rikkakasvit (Kuva 6). Rikkakasvien torjunta on luomussa haasteellista, kun luomutuotantoon sopivia kasvinsuojeluaineita rikkoja vastaan ei ole. Ohjeena on, että rypsi kylvetään riittävän myöhään, jotta maa olisi lämmin. Silloin rypsi lähtee nopeasti kasvuun ja pystyy hyvässä kasvussa ollessaan vastustamaan paremmin tuholaisia ja peittää nopeasti maan, mistä on etua kilpailussa rikkoja vastaan (http://www.agronet.fi/rypsi2000/). Tätä ohjetta luomuviljelijät noudattavat hyvin, jopa yli ohjearvojen, vain muutaman viljelijän kylväessä aiemmin kuin touko-kesäkuun vaihteessa (Kuva 7).

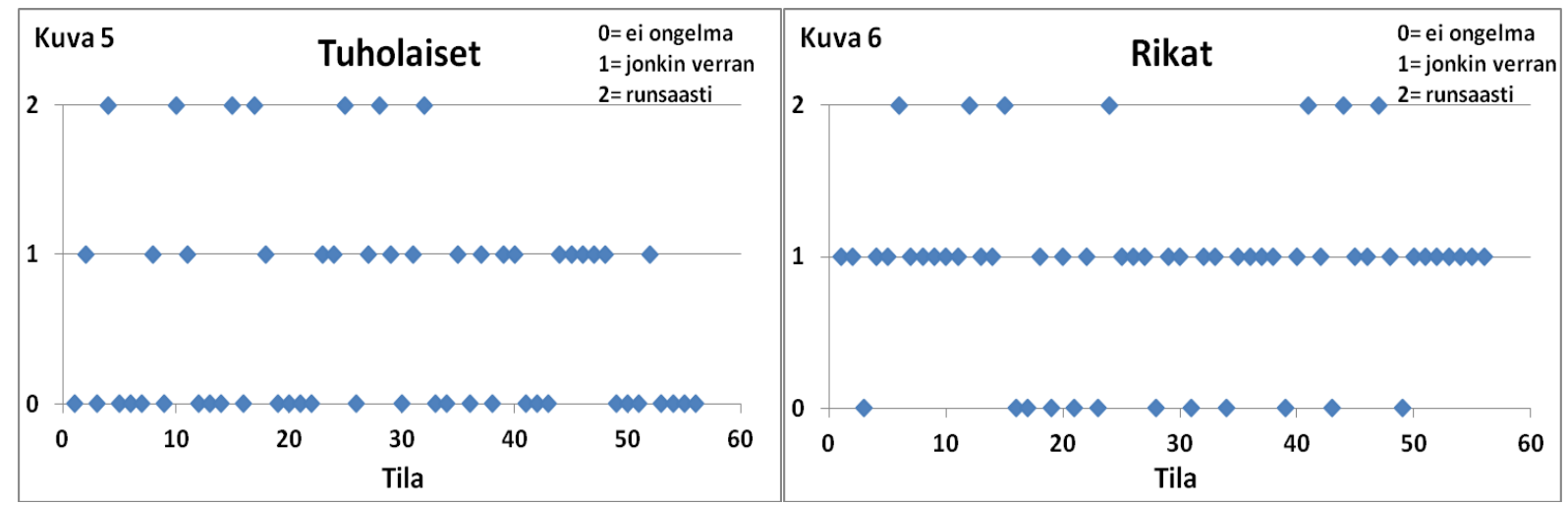

Kuva 5. Tuholaiset eivät ole yleinen ongelma, niitä on joko jonkin verran tai ei lainkaan, vain harvoin runsaasti. Kuva 6. Rikkoja on melkein jokaisella tilalla, vain 12 viljelijää 56:sta ilmoitti, ettei ongelmaa ole. $0=$ ei ongelma, 1=ongelmaa jonkin verran, 2= ongelmaa runsaasti. Tilojen sijainnit ELY-keskusalueittain, kts. Kuvan 1 teksti.

Rikkaongelman takia melkein kaikki haastatellut viljelijät käyttivät syyskyntöä. Vain yksi viljelijä käytti suorakylvöä (erittäin suuri tila). Jotkut viljelijät viivästyttävät syyskyntöä, jotta saisivat rikkakasvit ensin kasvuun ja sitten kynnöllä niiden juuret pintaan ja kasvit tuhottua. Keväällä äestetään maa moneen 
kertaan, aina välillä rikkojen kasvua odotellen (maa on "pikakesannolla"). Jotkut luomuviljelijät jopa kylvävät rypsiä juuri sellaisille lohkoille, joissa rikkaongelma on suuri, jotta he pääsisivät hillitsemään rikkojen kasvua kevään mittaan. Äestyksiin on käytettävissä monia keinoja, joista hanhenjalkaterät tai niiden erityisen tehokkaat sovellukset "Kvick Finn" (suomalainen tuote) tai "Kvik-Up" (tanskalainen tuote) ovat monella käytössä hyvin tuloksin. Myös nurmi, joka voidaan niittää ennen rikkojen siementämistä, auttaa rikkaongelmassa. Yksi ratkaisu rikkaongelmaan on rypsin kylväminen niin harvaan riviväliin, että väleihin pääsee haraamaan (Kuva 8). Joskus rypsipellot ovat niin puhtaita, että tavanomainen viljelijäkin olisi tyytyväinen (Kuva 9).
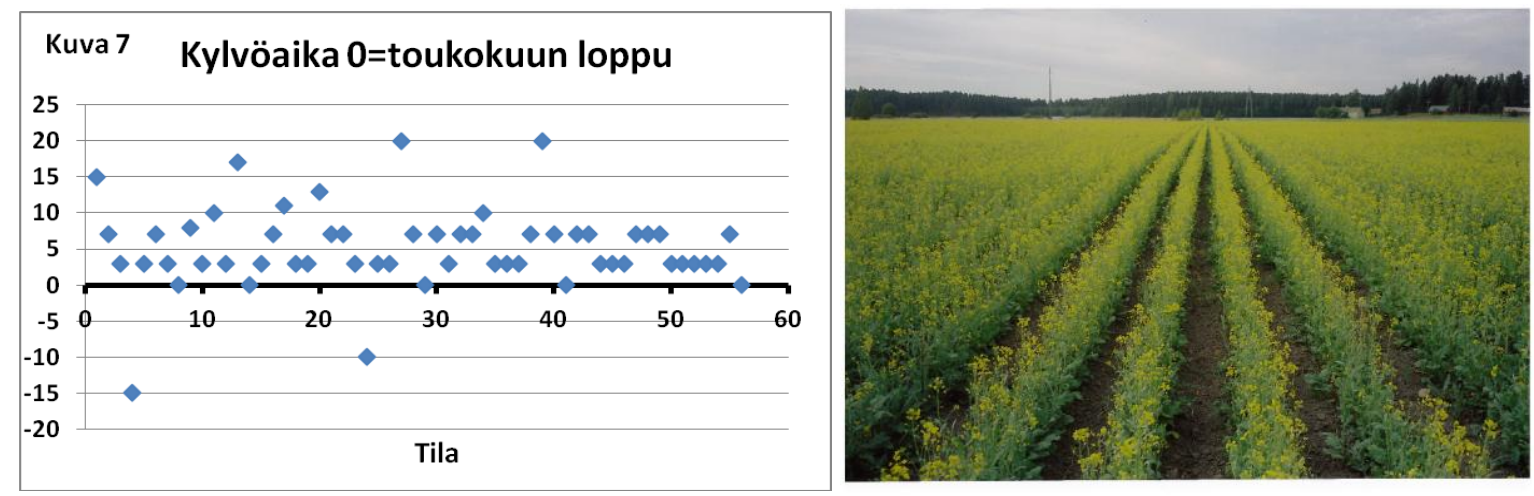

Kuva 7. Rypsi kylvetään jopa tavanomaisen viljelyn suosituksia myöhemmin. 0=kylvö toukokuun lopussa. Yli nollan: kylvö kesäkuussa, arvo=kesäkuun x. päivä. Alle nollan: -10: kylvö 20.toukokuuta, -15: kylvö 15. toukokuuta. Tilojen sijainnit ELY-keskusalueittain, kts. Kuvan 1 teksti.

Kuva 8. Rypsi on kylvetty niin suurella rivivälillä, että väleihin pääsee haraamaan rikat pois. Kuva: Antti ja Heikki Alitalo MTY, Antti Alitalo, Turku.

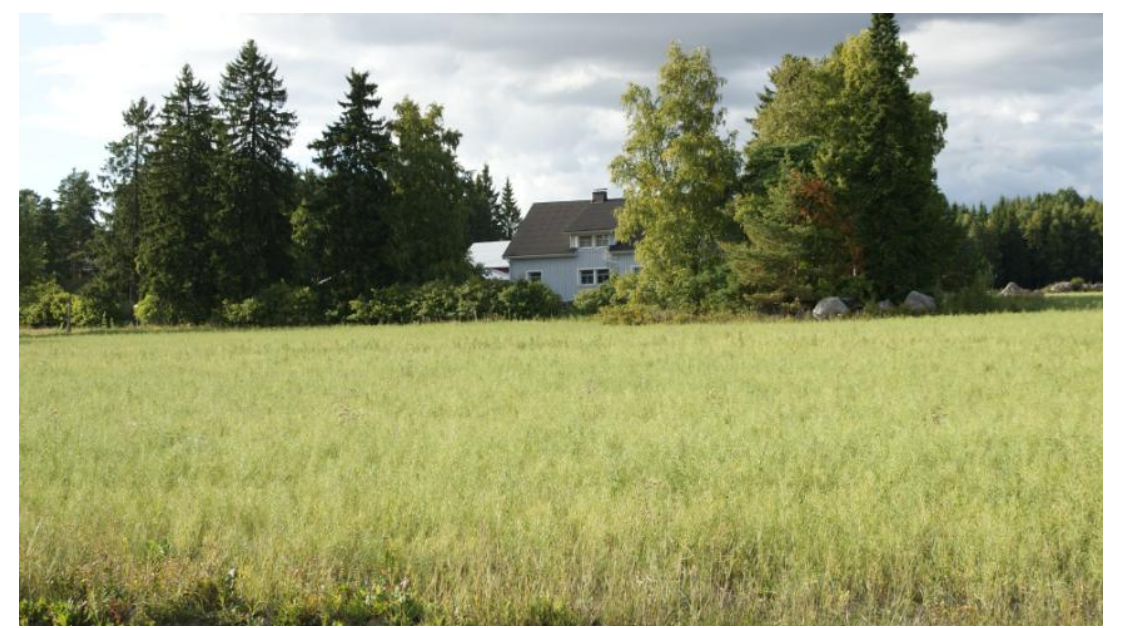

Kuva 9. Puhdas luomu-kevätrypsipelto Timo Niittymäen luomutilalla Kärjenniemellä. Kuva: Jos Helmich.

\section{Satoa tulee joskus paljon, joskus vähän: avainasemassa ravinteet, alkukasvukauden sää ja sään ääri- ilmiöt}

Ravinnetasojen ylläpito on yksi luomuviljelyn suurimpia ongelmia. Haastatellut viljelijät käyttivät kaikki viljelykiertoja, joissa palkokasvit olivat mukana. Pelkästään palkokasvin mukana olo ei aina riitä, etenkin, jos maassa on muun kuin typen puutetta. Fosforin puutetta voidaan helpottaa karjan-, sian-, broilerin-, hevosen- tai kalkkunan lannalla tai kompostilla. Lisäksi viljelijät käyttävät toisinaan säännöllisesti, toisinaan satunnaisesti liha-luujauhoa (esim. kauppanimi Viljo). Liha-luujauhossa on fosforia paljon suhteessa typpeen (NPK esim. 8-5-2, www.novarbo.fi), jolloin hyvän typpilannoitustason saamiseksi (esim. $80 \mathrm{~kg} \mathrm{~N} / \mathrm{ha}$ ) maahan tulee levitettyä fosforia $50 \mathrm{~kg} / \mathrm{ha}$.

Sadon onnistumisessa säätila on ratkaisevan tärkeä. Koska kylvö on tehtävä myöhään, mikä sinänsä auttaa rikka- ja tuholaisongelmassa, pelto ehtii usein kuivua liikaa ennen kylvöä, varsinkin, kun sitä äestetään 
moneen kertaan. Yksi viljelijä olikin tullut siihen tulokseen, että kylvää, kun maa on riittävän kuivaa traktoriliikenteelle, välittämättä lämpötiloista. Useimmiten kuitenkin kylvöaikaohjetta noudatetaan tarkkaan. Alkukasvukauden kuivuus koettiin kaikkein suurimmaksi satoja rajoittavaksi tekijäksi. Toinen esille tullut säähän liittyvä ongelma olivat rankkasateet. Esim. yhdellä tilalla oli rankkasade osunut lupaavaan, korjuuvalmiiseen rypsikasvustoon ja tyhjentänyt suurimman osan paloista, jolloin satoa ei juuri tullut.

Kylvömäärät olivat haastatelluilla tiloilla suositusten (http://www.agronet.fi/rypsi2000/) mukaisesti suhteellisen pieniä, yleensä 6-10 kg/ha (Kuva 10). Monet viljelijät olivat aloittaneet omatoimisen kokeilun, jossa he pienensivät kylvömäärää vähitellen tai kokeilivat pienellä kylvömäärällä hajakylvöä, mikä oli tuottanut hyvän tuloksen. Sadon määräksi saattoi tulla mitä tahansa nollan ja $2000 \mathrm{~kg} / \mathrm{ha}$ välillä (Kuva 11). Sadon määrän pysyminen hyvällä tasolla koettiinkin yhdeksi suurimmista luomu-kevätrypsin tuotannon ongelmista. Kun satoa saadaan, markkinat toimivat hyvin ja sadosta saadaan hyvä hinta. Sato menee tavallisesti ensin öljynpuristamoon ja sieltä saadaan puristusjäte valkuaisrehuksi joko omalle tai naapurin karjalle.

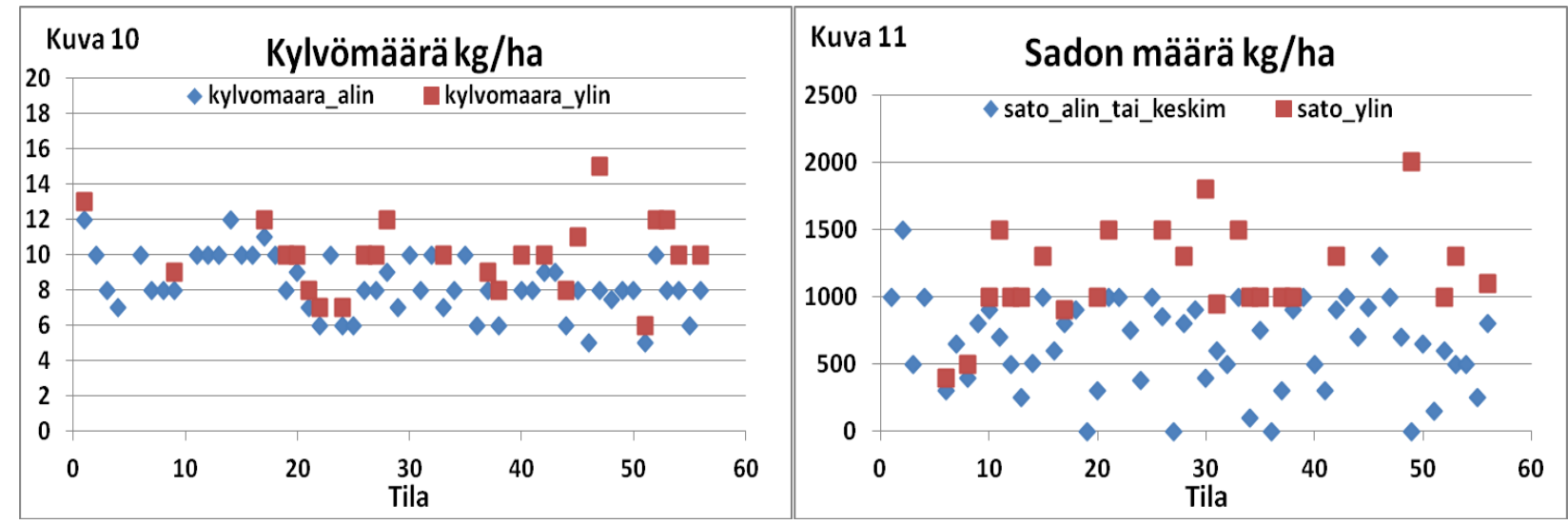

Kuva 10. Kylvömäärät ovat maltilliset. Tieto siitä, että vähemmälläkin pärjää on mennyt hyvin läpi.

Kuva 11. Erityisenä tiedustelun kohteena oli vuoden 2010 sato, mikä kuitenkin oli melkein kaikilla ollut kuivuuden takia huono. Jotkut viljelijät olivat kuitenkin tuonakin vuonna onnistuneet erinomaisesti joillakin lohkoilla. Huonosta sadosta ei haluttu useinkaan puhua, vaan esitettiin keskiarvosato. Kuvan arviot ovat useimmiten keskiarvosatoja tai haarukka X-x (alin-ylin). Nollasato saatiin etenkin, jos esim. tuholaiset tuhosivat sadon eikä uutta kasvustoa ehditty kylvää. Tilojen sijainnit ELY-keskusalueittain, kts. Kuvan 1 teksti.

\section{Johtopäätökset}

Luomu-kevätrypsin viljelijät noudattavat viljelyssä hyvin sekä rypsin viljelyn yleisiä ohjeita että luomuohjeita. Viljelijät ovat hämmästyttävän tyytyväisiä tulokseen. Tuki on hyvä ja sadosta saadaan useimmiten hyvä hinta. Lisäksi markkinat toimivat hyvin. Tuotannon suurimmat ongelmat ovat alkukasvukauden kuivuus, sään ääri-ilmiöt ja tuholaiset, joista kukin tekijä saattaa tuhota koko sadon. Eri syistä johtuva satotasojen vaihtelu on myös ongelma. Rikkakasveja on melkein aina jonkin verran, mutta niiden kanssa viljelijät pärjäävät huolellisella työllä. Positiivisina asioina tulivat haastattelujen kuluessa esiin perhekeskeinen toiminta ja hyvät naapuruussuhteet sekä yhteistyö muiden luomuviljelijöiden kanssa. Hyvin harva viljelijä näki tulevaisuuden raskaana, yleisvire oli toiveikas, vaikka maailma ympärillä muuttuukin.

\section{Kirjallisuus}

Rinne, M., Kuoppala, K., Ahvenjärvi, S. \& Vanhatalo, A. 2006. Rypsi soijaa parempi lypsylehmien valkuaistäydennys myös apilapitoista säilörehua syötettäessä. Teoksessa: Anneli Hopponen (toim.) Maataloustieteen päivät, 11.-12.1.2006. Suomen maataloustieteellisen seuran tiedote 21: $7 \mathrm{~s}$. 